\title{
Primary Splenic Hydatidosis
}

\author{
Mehmet Ozdogan ${ }^{a}$ Atac Baykal ${ }^{b}$ Mehmet Keskek ${ }^{c}$ Kaya Yorganci ${ }^{b}$ Erhan Hamaloglu \\ Iskender Sayek ${ }^{\mathrm{b}}$ \\ Departments of General Surgery, ${ }^{a}$ Ataturk Research Hospital, Bilkent, ${ }^{b}$ Hacettepe University Medical School and \\ ${ }^{\mathrm{c}}$ Numune Research Hospital, Sihhiye, Ankara, Turkey
}

Dear Editor,

We have read the original article 'Primary Splenic Hydatidosis' by Durgun et al. [1] with interest. The authors evaluated 14 patients with isolated splenic hydatid cyst. All their patients underwent elective splenectomy with a $28.5 \%$ complication rate and without any recurrence. They suggested splenectomy as an ideal procedure for the treatment of splenic hydatidosis.

In our series of splenic hydatidosis of the same patient size [2], we had performed spleen-preserving surgery, namely partial cystectomy and omentopexy in 2 patients with good long-term results. We also performed partial cystectomy and omentopexy in another patient successfully later on. Although the attempt of percutaneous drainage treatment of splenic cyst hydatidosis in 2 other patients failed in our study [2], a recent study from Turkey stated that percutaneous treatment modality could be applied with a very high success rate [3].

We think that, although splenectomy usually remains the treatment of choice for most of the surgeons, partial cystectomy and omentopexy should be performed whenever possible as a safe method that do not interfere with splenic functions. Percutaneous treatment of hydatid cyst of spleen needs to be evaluated further.

\section{References}

1 Durgun V, Kapan S, Kapan M, Karabicak I, Aydogan F, Goksoy E: Primary splenic hydatidosis. Dig Surg 2003;20:38-41.

2 Ozdogan M, Baykal A, Keskek M, Yorganci K, Hamaloglu E, Sayek I: Hydatid cyst of the spleen: Treatment options. Int Surg 2001;86: 122-126.

3 Ormeci N, Soykan I, Palabiyikoglu M, Idilman R, Erdem H, Bektas A, Sarioglu M: A new therapeutic approach for treatment of hydatid cysts of the spleen. Dig Dis Sci 2002;47:20372044.

\section{KARGER}

Fax +4161306 1234 E-Mail karger@karger.ch www.karger.com www.karger.com/dsu
Mehmet Ozdogan

Mertler sok. 41/7 Bestepe

TR-06510 Ankara (Turkey)

Tel. +90 532 3628403, Fax +90 3124809375

E-Mail mehmetozdogan01@superonline.com 